Communication

\title{
Promoting the China Health Modernization by Health Superhighway System
}

\author{
Lei Liu ${ }^{1,2, *}$, Xijun Zhao ${ }^{1}$ and Chuanqi He ${ }^{1,2, *}$ \\ 1 China Center for Modernization Research, Chinese Academy of Science, Beijing 100190, China; \\ zhaoxijun@mail.las.ac.cn \\ 2 School of Public Policy and Management, University of Chinese Academy of Science, Beijing 100049, China \\ * Correspondence: liul@mail.las.ac.cn (L.L.) \& hechuanqi@263.net (C.H.); Tel.: +86-10-6253-9187 (L.L. and C.H.)
}

Received: 8 October 2018; Accepted: 17 October 2018; Published: 26 October 2018

\begin{abstract}
We, China Centre for Modernization Research Chinese Academy of Sciences, released our $16^{\text {th }}$ annual China Modernization Report in 2017, whose topic focused on the world and China's health. The China Modernization Report 2017 analyzed world health modernization since 1700, covering healthy life, health service, healthy environment and health governance based on global 131 countries (Population $>1$ million). The long term trends and world frontiers of health modernization had been concluded, mainly for reference to promote the China health modernization. Based on these findings, the chief editor of the China Modernization Report, Prof. Chuanqi HE proposed the 'Health Superhighway System' in China Modernization Report 2017, aiming to provide the decision-making consultation and guidance of engineering practices for China's health modernization. Herein, we will give a brief introduction of research finding in China Modernization Report 2017, and especially show the details of 'Health Superhighway System' for promoting the China health modernization in future.
\end{abstract}

Keywords: health modernization; health superhighway system; china modernization report

\section{Introduction}

Health is the core premise of human development. There is a long-history for health research, and involves a wide range of subjects including medicine, biology, demography, anthropology, public health, health economics, health statistics, health sociology, public administration, etc. So, what is the health in the end? Different disciplines have different interpretations. At present, the authoritative definition is the one proposed by the World Health Organization, namely, health is a state of complete physical, mental and social well-being, and not merely the absence of disease or infirmity [1]. With the development of the times, the concept of health continues to evolve. On the basis of the above content and the concept of modernization in modernization science [2], it is believed that from the policy perspective, health modernization is a type of frontier change and international competition in world health since the 18th century; it is the frontier process of the formation, development, transformation and international interaction of modern health, the composite process of the innovation, selection, propagation and withdrawal of health elements, as well as the international competition and international differentiation in which countries endeavor to catch up with, reach, and keep up with the world's advanced level in health. Countries that managed to reach and keep up with the world's advanced level in health are health-developed countries, while the rest are developing ones. Swap between the two groups happens with a certain probability [3].

The China Modernization Report 2017 still follows the time series analysis, cross-sectional analysis and process analysis conducted in previous China Modernization Reports (2001 2016), in order to find long term trends and world frontiers of world health development, mainly for reference to promote the China health modernization. The analysis also covers 131 countries and $96 \%$ of the 
world's population (Population $>1$ million) over a time span of 300 years (1700 to 2015). The analysis framework of health modernization has been set from the customer-oriented perspective, including healthy life, health service, healthy environment and health governance, and 151 health indicators have been selected as analysis variables.

\section{Results}

\subsection{Basic facts of China health modernization}

China health modernization can be traced back to the middle and late of the 19th century, more than 100 years later than western countries. But, there is a big leap in China health modernization since 1950's. In 2015, China health modernization ranked 59 among 131 countries, belonging to the elementary developed group [3]. Compared with the health-developed countries, we could find that China health modernization faced many challenges from different aspects. Here are 4 highlight critical issues showing as follows:

1. Nurses and midwives (per 1,000 people)

There is a big gap between China and the health-developed countries in health human resources, especially in nurses and midwives. According to the World Bank Database, China showed that the average scale of nurses and midwives was 2.4 per 1,000 people in 2015, while United Kingdom 8.4 per 1,000 people, Germany 13.4 per 1,000 people, Japan 11.2 per 1,000 people, Sweden 11.9 per 1,000 people, Norway 16.9 per 1,000 people (Figure 1). The average of developed countries is nearly 4 times of China. There is an obvious deficiency in health service capacity, thus resulting in low quality of healthcare.
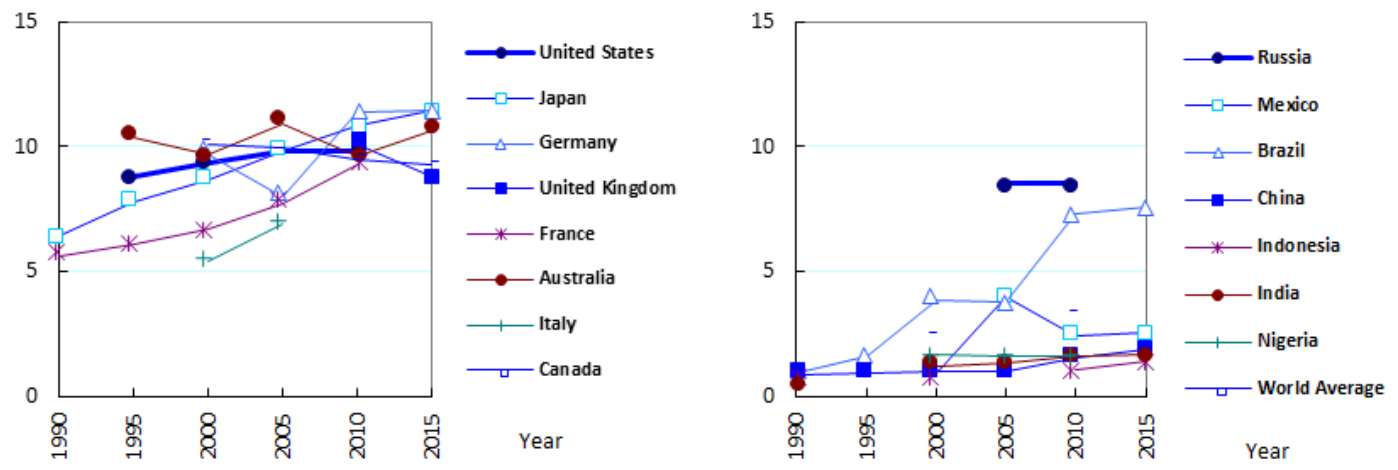

Figure 1. 19902015 Nurses and midwives (per 1,000 people) in selected countries. Data source: World Bank, 2017 [4].

\section{Quality of environment}

Currently, changing the model of development and improving the quality of development is a hot topic in China. Governments, civil society organization, private sector, scientific community and the other stakeholders, especially including individuals, everyone pays more attention to the environmental quality. Take PM 2.5 air pollution as an example, China exhibited 57.2 micrograms per cubic meter (mean annual exposure) in 2015, while the average of high-income countries and world are 16.3 and 41.7 micrograms per cubic meter, respectively (Figure 2). We still need to struggle for the blue sky. 

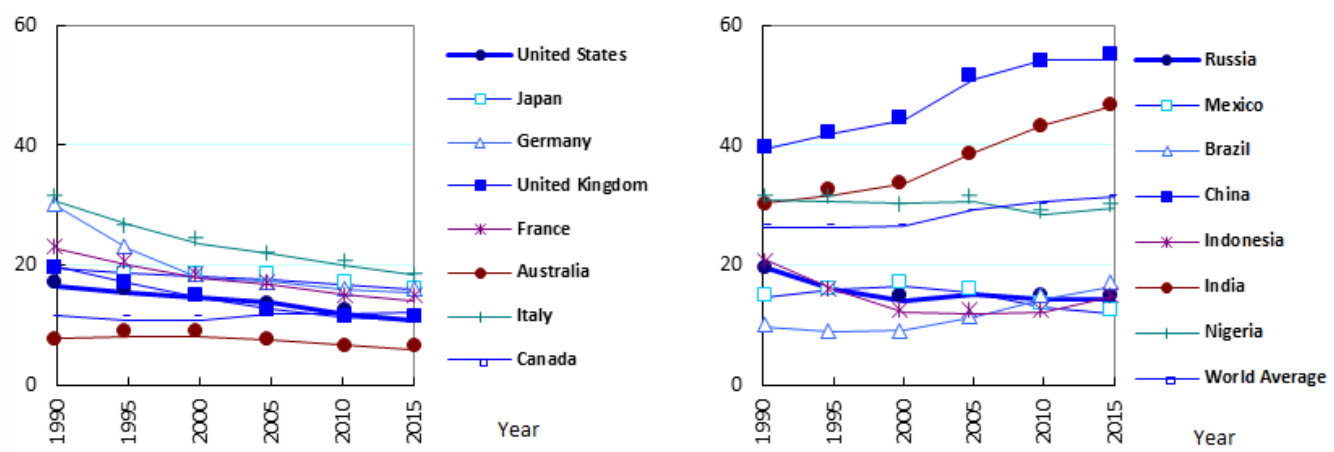

Figure 2. 19902015 PM 2.5 air pollution (micrograms per cubic meter, mean annual exposure) in selected countries. Data source: World Bank, 2017 [4].

3. Public health expenditure ( $\%$ of government expenditure)

World Health Organization declared that governments have a responsibility to ensure that everyone can obtain the health services they need and that all are protected from the financial risks associated with using them; They are also responsible for ensuring that a range of population-based services focusing on prevention and promotion is available; They also must ensure that all providers, public and private, operate appropriately and attend to patients' needs cost effectively and efficiently[5]. Public health expenditure is a core indicator showing government's responsibility to national health. The official statistical data showed that the public health expenditure (\% of government expenditure) of China was about $10 \%$ in 2015, while the average of developed countries was about $17 \%$ (Figure 3 ).
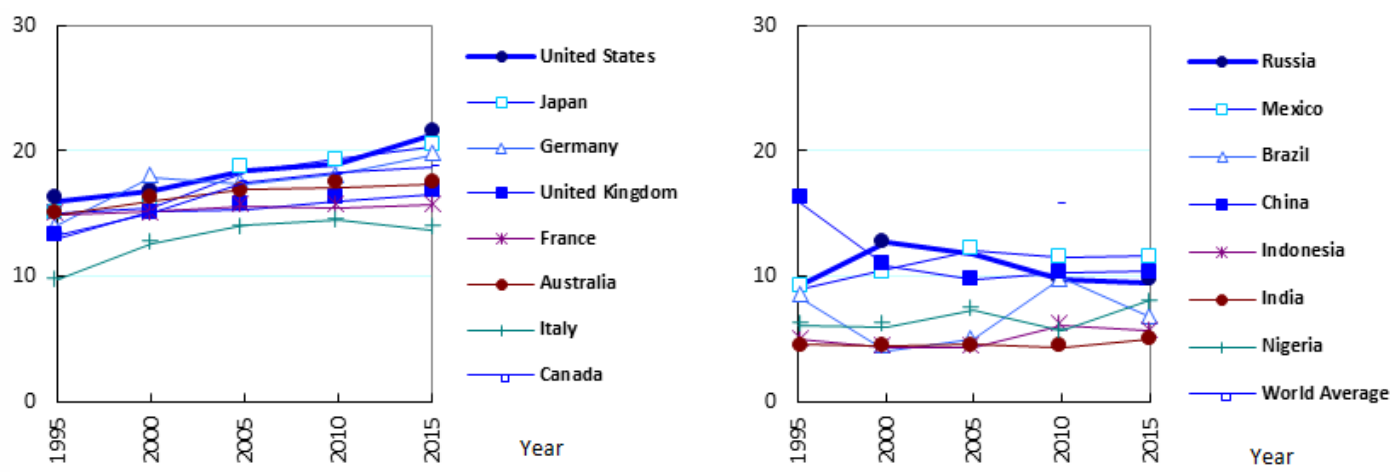

Figure 3. 19952015 Public health expenditure (\% of government expenditure) in selected countries. Data source: World Bank, 2017 [4].

4. Health industry

Health is not just a value in itself, but also a strong economic driver for growth. Taking the European Union for an example, health industry accounted for nearly $8 \%$ of the EU's gross domestic product in 2015, top economic sector in the EU (Figure 4) [6]. Comparatively, in the same period China was estimated about $2 \%$ of gross domestic product. The facts have proved that there is a strong evidence of the link between health and economic performance: a population in good health is a sine qua non for attaining smart, sustainable and inclusive growth [7]. 

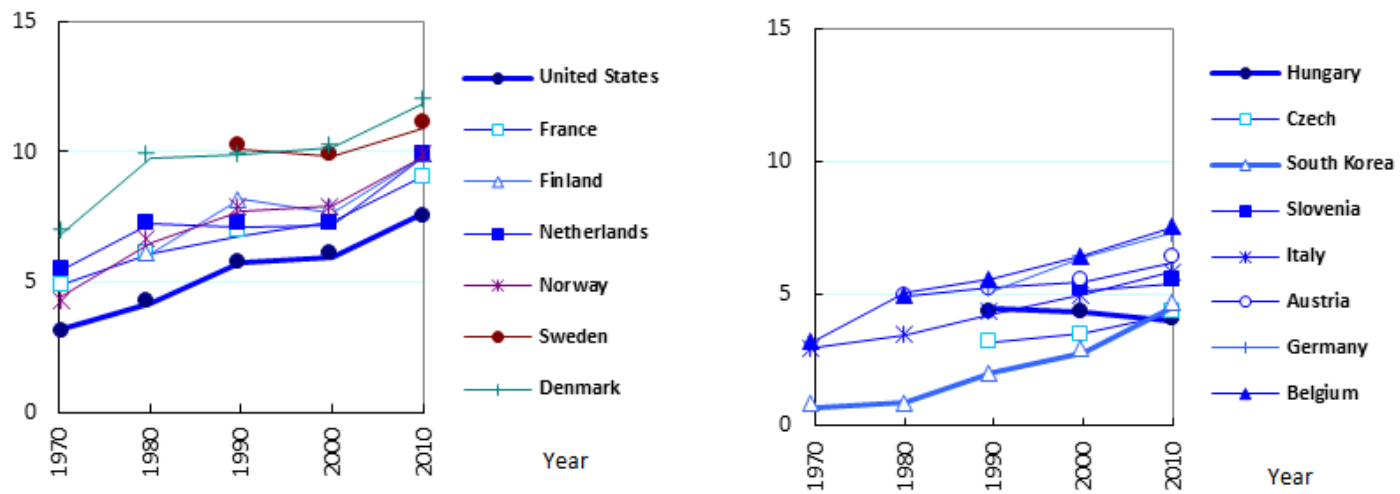

Figure 4. 19702010 Value added of health industry (\% of GDP) in selected countries. Data source: OECD, 2017 [8].

\subsection{Health Superhighway System for Promoting the China Health Modernization}

Based on the facts of world and China health modernization, Prof. HE proposed the 'Health Superhighway Strategy' to promote the China health modernization in China Modernization Report 2017. He believed that there were five aspects of China health modernization, including health system modernization, healthy life modernization, health service modernization, healthy environment modernization, and health governance modernization. We could learn from the development experience of China high-speed railway, that is 'System Upgrade \& 4-Wheels Drive', and propose the development strategy of China health modernization, namely 'Health Superhighway System' (Figure $5)$.

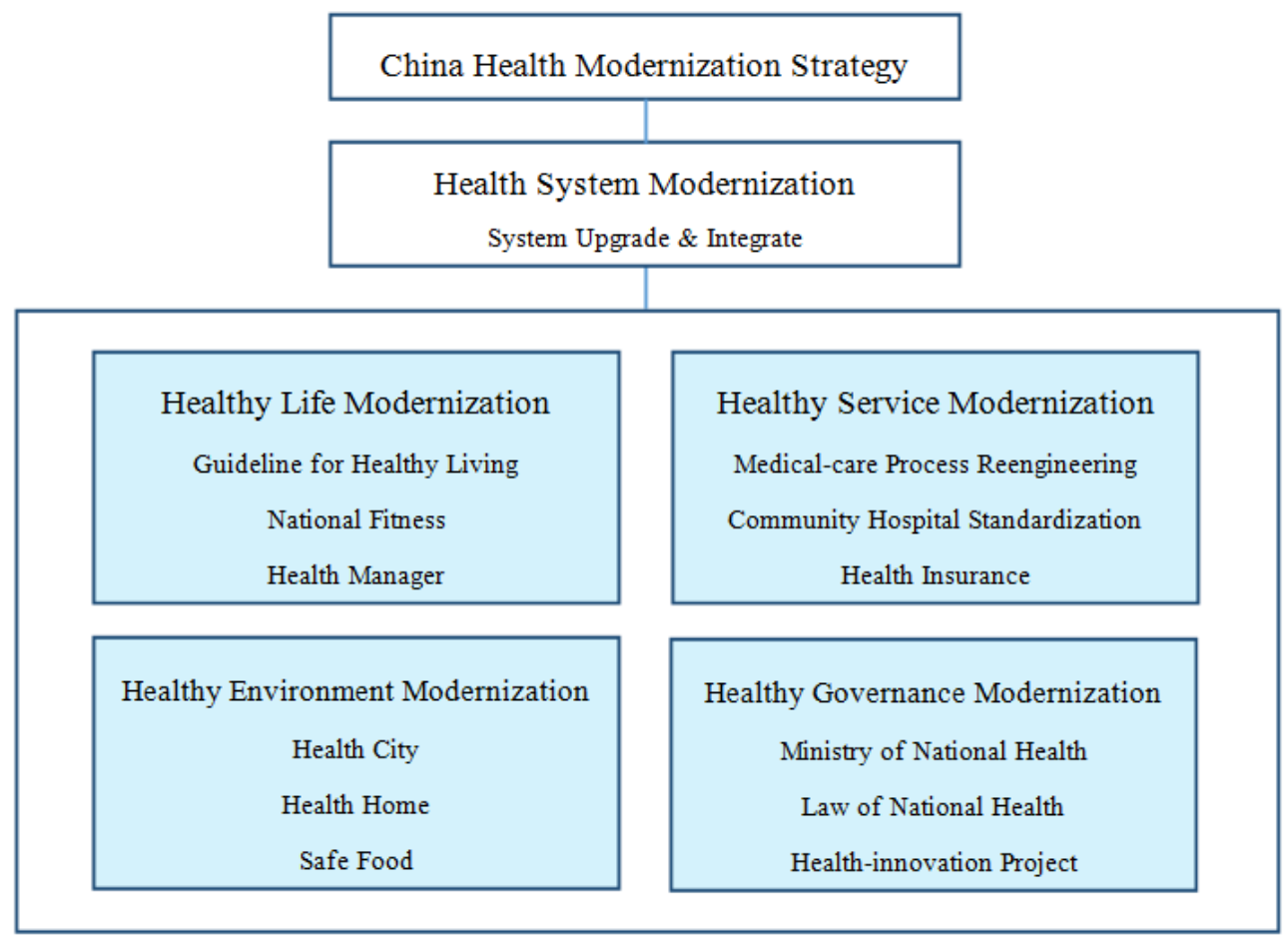

Figure 5. Diagram of health superhighway system. Source: He, 2017 [3].

- System Upgrade means that China should promote the transformation from medical care system to national health system.

- 4-Wheels Drive means China health modernization should take the modernizations of healthy life, health service, healthy environment and health governance as driving force. Healthy life would control and reduce the personal health risks; high quality of health service would make patients quick recovery; high quality of environment would enable everyone to live fit and healthy; good health governance would achieve sustainable development. 
During the last decade, China railway system has successfully upgraded from industrial age's railway system to information age's high-speed railway system. Just like the China railway system, China health system also needs to transform and upgrade from industrial age's discrete medical care system to information age's integrated national health system (Table 1).

Table 1. Comparison of medical care system and national health system.

\begin{tabular}{ccc}
\hline Item & Medical Care System & National Health System \\
\hline Principle & Disease prevention-oriented & Humanism-oriented \\
Center & Heal the wounded \& rescue the dying & Health needs \\
Object & Patients recovery & Good health and long life \\
System & Discrete medical care system & Integrated national health system \\
Features & Medical care system in industrial age & National health system in information age \\
\hline
\end{tabular}

Source: He, 2017 [3].

Health superhighway system was proposed mainly based on the division of labor. There are three key behavior subjects in health superhighway system, including individuals, health institutions and governments. Division as well as cooperation of these three parts is the basic premise of the China health superhighway system. On a personal level, individual has a responsibility to ensure that she/he tried her/his best to control and reduce the health risk; on a health institution level, they are responsible for improving the quality of health service, operating appropriately and attending to patients' needs cost effectively and efficiently; on a government level, it has a responsibility to enhance the health governance and promote the health equality and sustainability.

Healthy Life Agenda, Healthcare Quality Improvement Project, Environmental Health Project and Health Governance Improvement Project, these four projects were put forward as 4-wheels of China health superhighway system to drive the China health modernization. The object of Healthy Life Agenda is mainly focused on the individual and families, aiming to improve the health literacy and reduce health risk. Two initiatives, Medical-care process reengineering and Community hospital standardization, were suggested listing in Healthcare Quality Improvement Project to improve the healthcare quality and health quality of patients. Environmental Health Project would shoot for good environment and safe food. The mission of Health Governance Improvement Project is achieving the universal coverage and keeping sustainable development.

Table 2. 4-wheels drive of China health superhighway system.

\begin{tabular}{|c|c|c|c|c|}
\hline Item & $\begin{array}{l}\text { Healthy Life } \\
\text { Agenda }\end{array}$ & $\begin{array}{l}\text { Healthcare Quality } \\
\text { Improvement Project }\end{array}$ & $\begin{array}{c}\text { Environmental Health } \\
\text { Project }\end{array}$ & $\begin{array}{c}\text { Health Governance } \\
\text { Improvement } \\
\text { Project } \\
\end{array}$ \\
\hline $\begin{array}{c}\text { Behavior } \\
\text { subject }\end{array}$ & $\begin{array}{l}\text { Individuals and } \\
\text { families }\end{array}$ & Healthcare institutions & $\begin{array}{c}\text { Government and } \\
\text { whole society }\end{array}$ & $\begin{array}{l}\text { Government and } \\
\text { health institutions }\end{array}$ \\
\hline Mission & Reduce sick & $\begin{array}{c}\text { Early treatment and } \\
\text { quick recovery }\end{array}$ & $\begin{array}{l}\text { Good environment } \\
\text { and safe food }\end{array}$ & $\begin{array}{l}\text { Universal coverage } \\
\text { and sustainability }\end{array}$ \\
\hline Object & Control health risk & $\begin{array}{l}\text { Improve the quality of } \\
\text { health service }\end{array}$ & $\begin{array}{l}\text { Improve the } \\
\text { environment }\end{array}$ & $\begin{array}{l}\text { Promote the equality } \\
\text { and sustainability }\end{array}$ \\
\hline Duty & $\begin{array}{l}\text { Improve the } \\
\text { health literacy and } \\
\text { reduce health risk }\end{array}$ & $\begin{array}{l}\text { Improve the health } \\
\text { quality of patients and } \\
\text { healthcare quality }\end{array}$ & $\begin{array}{l}\text { Improve the } \\
\text { environmental qualtiy } \\
\text { and construct the } \\
\text { health city and home }\end{array}$ & $\begin{array}{l}\text { Enhance the health } \\
\text { governance and } \\
\text { reduce the health } \\
\text { imparity }\end{array}$ \\
\hline Initiatives & $\begin{array}{l}\text { Total-planning of } \\
\text { healthy life; } \\
\text { Behavior guide to } \\
\text { healthy living }\end{array}$ & $\begin{array}{l}\text { Medical-care process } \\
\text { reengineering; } \\
\text { Community hospital } \\
\text { standardization }\end{array}$ & $\begin{array}{l}\text { Environmental qualtiy } \\
\text { improvment plans; } \\
\text { Safe food plan }\end{array}$ & $\begin{array}{l}\text { Establish the } \\
\text { ministry of national } \\
\text { health; } \\
\text { Health-innovation } \\
\text { Project }\end{array}$ \\
\hline
\end{tabular}

Source: He, 2017 [3].

\section{Conclusions}


This paper gives a brief introduction of the current highlight critical issues of China health modernization and the corresponding measures 'Health Superhighway System'. Comparing with the health-developed countries, China health modernization currently faces many challenges from different aspects, especially in health human resource, health environment, public health expenditure and health industry. Accordingly, we try to address these problems by 4 -wheels drives of Health Superhighway System and a serial of projects and initiatives were proposed, aiming to provide the decision-making consultation and guidance of engineering practices for China's health modernization.

Acknowledgments: This research was supported by 'Health China 2030 Planning' Foundation of National Health Commission of the People's Republic of China.

Author Contributions: Chuanqi He proposed the Health Superhighway System; Xijun Zhao provided the facts of China health; Lei Liu analyzed the data and wrote the paper.

Conflicts of Interest: The authors declare no conflict of interest.

\section{References}

1. World Health Organization. Constitution of the World Health Organization-Basic Documents, Fortyfifth edition, Supplement, October 2006. Available online:

http://www.who.int/governance/eb/who_constitution_en.pdf (accessed on 10 October 2018).

2. He, C.Q. Modernization Science; Springer: London New York, 2012.

3. He, C.Q. China Modernization Report 2017: Health Modernization Study; Peking University Press: Beijing, China, 2017.

4. World Bank. World development indicators, 2017. Available online: http://databank.worldbank.org/data/reports.aspx?source=world-development-indicators (accessed on 10 October 2018).

5. World Health Organization. The World Health Report: Health Systems Financing: The Path to Universal Coverage; WHO Press: Geneva, Switzerland, 2010.

6. Liu, L. Health China 2030: Study on the health indicators and development goals. Sci. Modernization 2017, $71,22-54$.

7. European Commission. Regulation of the European parliament and of the council: Establishing a health for growth programme, the third programme of EU action in the field of health for the period 2014-2020. Available online: http://www.europarl.europa.eu/RegData/docs_autres_institutions/commission_europeenne/sec/2011/132 2/COM_SEC(2011)1322_EN.pdf (accessed on 10 October 2018).

8. OECD. Database Health. 2017. Available online: https://data.oecd.org/health.htm (accessed on 10 October 2018).

(C) 2018 by the authors; licensee MDPI, Basel, Switzerland. This article is an open access article distributed under the terms and conditions of the Creative Commons by Attribution (CC-BY) license (http://creativecommons.org/licenses/by/4.0/). 